The Next American Revolution 
The publisher gratefully acknowledges the generous support of the African American Studies Endowment Fund of the University of California Press Foundation. 


\title{
The Next American Revolution
}

\author{
Sustainable Activism \\ for the Twenty-First Century \\ Updated and Expanded Edition
}

Grace Lee Boggs

With Scott Kurashige

Foreword by Danny Glover

New Afterword with Immanuel Wallerstein

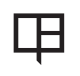

UNIVERSITY OF CALIFORNIA PRESS

Berkeley Los Angeles London 
University of California Press, one of the most distinguished university presses in the United States, enriches lives around the world by advancing scholarship in the humanities, social sciences, and natural sciences. Its activities are supported by the UC Press Foundation and by philanthropic contributions from individuals and institutions. For more information, visit www.ucpress.edu.

University of California Press

Berkeley and Los Angeles, California

University of California Press, Ltd.

London, England

(C) 20II, 2012 by The Regents of the University of California

First paperback printing 2012

Library of Congress Cataloging-in-Publication Data

Boggs, Grace Lee.

The next American revolution : sustainable activism for the twenty-first century / Grace Lee Boggs with Scott Kurashige ; foreword by Danny

Glover.

p. $\quad \mathrm{cm}$.

Includes bibliographical references and index.

ISBN 978-0-520-27259-0 (paper : alk. paper)

I. Social action-United States-History-2ist century. 2. Social movements-United States-History—2Ist century. 3. Sustainable development-United States-History—2ist century. I. Kurashige, Scott. II. Title.

HN65.B634 20II

$303.48^{\prime} 409730905 \mathrm{I}-\mathrm{dc2} 2$

2010039659

Manufactured in the United States of America

$\begin{array}{llllllllll}20 & \text { I9 } & \text { I8 } & \text { I7 } & \text { I6 } & \text { I5 } & \text { I4 } & \text { I3 } & \text { I2 } \\ \text { I0 } & 9 & 8 & 7 & 6 & 5 & 4 & 3 & 2 & \text { I }\end{array}$

This book is printed on Cascades Enviro 100, a 100\% post consumer waste, recycled, de-inked fiber. FSC recycled certified and processed chlorine free. It is acid free, Ecologo certified, and manufactured by BioGas energy. 
To Fimmy Boggs, who thought and acted dialectically 
This page intentionally left blank 